Open Access

\title{
Managing the innovation legitimacy of the sharing economy
}

Jiyoung Hwang

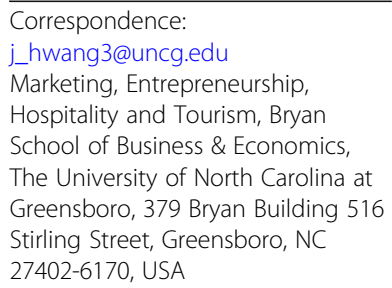

Correspondence:

j_hwang3@uncg.edu

Marketing, Entrepreneurship,

Hospitality and Tourism, Bryan

School of Business \& Economics,

The University of North Carolina at Greensboro, 379 Bryan Building 516

Stirling Street, Greensboro, NC

27402-6170, USA

\begin{abstract}
Sharing economy has become widespread globally as an innovative service business model. However, some of sharing economy's socially irresponsible practices have led critics to challenge their legitimacy. Drawing upon legitimacy theory, this research evaluates the legitimacy and corporate social responsibility (CSR) of sharing economy. The current stance of sharing economy's legitimacy is discussed regarding regulations; legal, tax, and labor issues; politics and lobbying behaviors; social inequality; and societal and economic impact, along with its core concept, sharing. This paper further delineates how CSR and CSR communication can help sharing economy firms manage the challenged legitimacy. As one of the first research attempts, the current paper sheds lights on the dark side of sharing economy and the value of CSR to resolve some concerns about its legitimacy.
\end{abstract}

Keywords: Sharing economy, Legitimacy, Corporate social responsibility, CSR communication

\section{Introduction}

Consumers have quickly embraced sharing economy services like Uber and Airbnb. When people visit a new area, searching affordable accommodations on Airbnb and arranging a ride using Uber have become a new normal. This trend is rising in many countries as the idea of sharing economy and sharing economy firms have gone global. In 2017, Airbnb operated in over 65,000 cities in more than 191countries with over 3 million listings worldwide; to date, 200 million guests have stayed at one of these locations [1]. In June 2017, Uber's total number of rides reached 5 billion in cities including Mumbai and Moscow, with a presence in 24 countries on six continents [2]. The exponential growth of sharing economy has been propelled by positive contributions such as increased employment opportunities for individuals, generally cheaper and more convenient services for consumers, and boosted vibrancy for local communities.

At the same time, various concerns and controversies have also emerged about practices of sharing economy (e.g., tax, regulations, labor, and consumer issues). For instance, Uber has a notorious reputation for its treatment of drivers and a workplace culture associated with sexual harassment and discrimination, which led the recent resignation of the CEO. Airbnb has been linked to the surge in housing costs in big cities like San Francisco and New York. Other issues such as taxes and legal claims are also arising. Some critics [3] even argue that calling sharing economy services "sharing" is a misnomer. In response, sharing economy corporations have taken several

(c) The Author(s). 2019 Open Access This article is distributed under the terms of the Creative Commons Attribution 4.0 International License (http://creativecommons.org/licenses/by/4.0/), which permits unrestricted use, distribution, and reproduction in any medium, provided you give appropriate credit to the original author(s) and the source, provide a link to the Creative Commons license, and indicate if changes were made. 
approaches to combat negative perceptions and societal pressures, such as significant efforts for corporate social responsibility (CSR hereafter). Uber has recently announced $\$ 3$ million in support for social causes, including \$1.2 million in support for coding education for females [4]. Despite those efforts, however, the negative sentiments about sharing economy still largely remain.

As such debates about sharing economy are centered on the moral, environmental, and ethical claims of sharing economy firms, and these debates are still ongoing and unresolved, it is timely to explore these businesses' roles in society, social responsibilities, and legitimacy. Legitimacy is one of the crucial factors for firms' success [5] as it allows continuous resource flow and support from constituents of an organization [6]. Given the rise of sharing economy and increasing debates about its positive and negative impact on national/international societies, in-depth discussion about the legitimacy of sharing economy is essential. Because legitimacy is a "yardstick" of the discussion in the CSR field [7], researchers have discussed CSR along with firms' legitimacy [8], yet businesses challenge the fundamental assumption of CSR (i.e., that conformity with societal rules is the basis for legitimacy), particularly when it comes to corporate activities across countries and cultures [8]. These debates about CSR apply to sharing economy, a global phenomenon. In the literature, much research has focused on the positive side of sharing economy and consumers' positive responses to sharing economy [9-12], but very few researchers have discussed the legitimacy, ethical roles, or CSR of sharing economy. Questions about the legitimacy of sharing economy need to be answered to justify the global role of sharing economy businesses. This need calls for comprehensively evaluating sharing economy's past and its current legitimacy in order to give these businesses a better future.

Thus, the current study comprehensively reviews sharing economy, the negative side as well as the positive, and its challenged legitimacy. We further highlight the crucial link between CSR and legitimacy of sharing economy. Guided by legitimacy theory [5], we evaluate the stance of sharing economy and suggest necessary and effective approaches to enhance legitimacy. This paper makes several theoretical contributions: (1) comprehensive theory-based reviews of why and how the legitimacy of sharing economy has been challenged, despite very positive initial reactions to sharing economy, and (2) insights into how to better resolve challenged legitimacy of sharing economy through CSR communication. In addition, sharing economy is still in a nascent state [13], and most research has focused on the sunny side of sharing economy and positive responses of consumers to sharing economy $[11,12]$. Thus, it is important to also address the dark side of sharing economy [14] through a theoretical lens. These insights are pivotal for justifying the presence of sharing economy firms and to overcome the current controversies and challenges to build long-term success for sharing economy. Therefore, we focus on the following questions:

RQ1: What is the current stance of sharing economy? What are the sources of controversies and dark side of sharing economy?

RQ2: How has the dark side of sharing economy challenged the legitimacy of sharing economy?

RQ3: How can sharing economy resolve concerns about its challenged legitimacy?

What are the roles of CSR in this regard? 
The rest of the paper is organized as follows. First, we discuss sharing economy as a global phenomenon and review the academic literature on this subject. Next, we discuss the importance of legitimacy and how legitimacy is related to CSR. Then, we elaborate why and how the legitimacy of sharing economy has been challenged regarding regulatory/legal concerns, tax/labor concerns, consumer safety, social inequality, political standpoints, and economic/societal impact. Finally, we present theoretical and managerial implications, followed by limitations and directions for future research. Figure 1 presents the conceptual framework of this paper.

\section{Sharing economy as a global phenomenon}

Sharing economy is an umbrella term that describes an emerging consumption trend: online peer-to-peer economic activities for sharing among consumers through intermediary service firms. The act of sharing is nonreciprocal pro-social behavior "that involves the act and process of distributing what is ours to others for their use and/or the act and process of receiving or taking something from others for our use" $[15,16]$. Although sharing has always existed in human society, this type of sharing behaviors and the widespread phenomenon of sharing economy are still new, so no term for this phenomenon has been widely agreed upon [17]. Thus, several terms have been adopted in academic and practical arenas, such as collaborative consumption [9], access-based consumption [18], the Mesh [19], sharing [20], and collaborative economy [21, 22]. Botsman [21] defines sharing economy as "an economic system based on sharing underused assets or services, for free or for a fee, directly from individuals." She stresses that sharing economy is based on peer-to-peer marketplaces building upon social trust among social strangers. Sharing economy is also defined as a special case of consumer-to-consumer $(\mathrm{C} 2 \mathrm{C})$ e-commerce [23]. Habibi et al. [24] interpret sharing economy on a continuum ranging from commercial to idealistic, in which idealistic platforms, e.g., Couchsurfing, focus more on social and sustainable goals than do

Emerging Dark Side of

Sharing Economy

- Regulatory/legal concerns

- Tax/labor issues

- Consumer concerns

- Social inequality

- Politics and lobbying

- Economic/societal impact

- Notion of sharing
Legitimacy of Sharing Economy

- Pragmatic legitimacy

- Cognitive legitimacy

- Moral legitimacy

Managing Legitimacy through CSR Communication

- More effective and transparent CSR communication

○ 5 tactics (e.g., Du and Vieira (2012))

- actively engaging stakeholders

- multi-media platforms including social media

- Development of more sophisticated measures of security/ privacy protection

- More fair and healthy work environment

Fig. 1 Review of CSR and legitimacy of sharing economy and role of CSR communication 
commercial platforms. Throughout this paper, we use the term sharing economy to refer to various kinds of sharing services.

The exponential growth of sharing economy across the globe has been propelled by economic benefits from sharing economy services [25] and advanced communication/social technologies. As a result, people perceive ownership as less important and are more willing to use sharing economy services [9, 26]. For example, according to a recent Nielsen poll of more than 30,000 Internet users, $23 \%$ of the survey participants indicated that they were willing to rent their power tools to neighbors [25]. Moreover, with the emergence of digital intermediaries, reputation-based trust has facilitated people's sharing behaviors online, where trust is an important issue [21]. Although sharing and related modes of access have received growing attention from academics, research on sharing economy is still nascent and mostly adopts macro-perspectives and focuses on the roles of sharing intermediaries [27]. Some empirical studies of individuals' motivations for using sharing economy reveal that utilitarian aspects (e.g., saving resources and costs, social utility) are users' primary motives [28]. Other studies [11] show the important role of hedonic value perceptions (vs. utilitarian and symbolic values) in young consumers' attitude toward and intention to use sharing economy services. Similarly, Bucher et al. [10] confirm that moral, social-hedonic, and monetary motivations play important roles in individuals' attitudes toward sharing their possessions with others online. They also find that social-hedonic motives had the strongest impact on attitude, followed by moral and then monetary motives, and that motives are determined by materialism, sociability, and volunteering. Lawson et al. [12] demonstrate that significant factors for consumers' attitudes and intention to use sharing economy services (e.g., economic consciousness, variety seeking, materialism, status consumption) may depend on the consumer clusters. Other researchers depict sharing as inherently ecological and pro-social (e.g., sharing contributes to sustainable environmental practices) and thus such altruistic motives drive people's sharing behaviors $[15,20]$.

While sharing economy is practiced through various platforms, with smaller firms in various business arenas, a small number of major services (Uber, Lyft, and Airbnb) dominate the market. The major players like Uber have become global. Uber was valued at $\$ 68$ billion in December 2016, taking only 6 years to surpass the valuation of 100-year-old companies like GM and Ford as well as traditional transportation providers like Hertz and Avis [29]. Airbnb is operating in over 65,000 cities in more than 191 countries. Lyft is relatively smaller than Uber and Airbnb, but after its business embarked in June 2012, Lyft has expanded its services to 300 cities in the USA, 1 million rides per day. The company was valued at $\$ 7.5$ billion in April 2017. Its global expansion to Canada is coming at the end of 2017. Such growth indicates that many individuals are increasingly accustomed to use sharing economy for everyday activities such as shopping and travel.

Sharing economy become a global phenomenon that promotes many local copycats of larger sharing economy businesses. The popularity of Uber has led to the success of BlaBlaCar, a long-distance ride-sharing service, in France. Customers' familiarity with AirBnB and co-working spaces such as Shared and Citizen Space have triggered the introduction of very similar firms in many countries. For instance, South Korea has So-Car (similar to Zipcar), Kozaza (similar to AirBnB), and D-Camp (similar to Citizen 
Space). In China, Didi Chuxing, a copycat of Uber, took over Uber's business in China and then expanded over five continents [30].

Additionally, as sharing economy services have exponentially diffused through markets and consumers increasingly adopt these services but it also has disrupted the current market [31]. Due to sharing economy, some of traditional businesses had to modify existing services and/or launch new services that embrace the notion of sharing economy. For example, taxi companies are heavily regulated and must purchase expensive licenses to operate. The introduction of Uber, however, has not only reduced the value of these licenses but has left taxi firms unable to sell their licenses as expected and unprotected from such rapid devaluation. License values have dropped anywhere from 25\% (New York) to 33.3\% (Chicago) [29]. More importantly, Uber's entry has reduced demand for taxis anywhere from 8\% (New York) to 65\% (San Francisco) in only 2 years [29]. On the other hand, some companies have modified existing services to attract sharing economy consumers. In Germany, BMW launched DriveNow in 2011 as a version of Zipcar for luxury vehicles. Volkswagen introduced Quicar through which consumers can ride 200 short-term rental vehicles across cities in 50 locations. Peugeot and Daimler, two car manufacturers, have embraced the ride-sharing idea by offering car rental services through memberships and mobile apps, respectively [32]. Daimler is exploring expanding this service to more than just Daimler vehicles, creating an app that works much like Uber (matching drivers and passengers) and connects to Facebook and Twitter feeds, allowing both the driver and rider to rate each other after the completion of the trip. These are only a few examples of changes in traditional businesses triggered by the rise of sharing economy.

\section{Sharing economy's legitimacy}

Legitimacy can be defined as "a generalized perception or assumption that the actions of an entity are desirable, proper, or appropriate within some socially constructed system of norms, values, beliefs, and definitions" [5]. As this definition implies, conformation with social norms, values, and expectations is an important requirement for legitimacy [33]. Legitimacy is crucial for organizations' survival because without legitimacy, organizations can be less stable and unable to grow [5].

Suchman [5] identifies three types of organizational legitimacy: pragmatic, cognitive, and moral. First, pragmatic legitimacy builds upon self-interested calculation of benefits from the company's activities (e.g., cost reduction, output of the macro economy system) for its audience (e.g., stakeholders). In this view of pragmatic legitimacy, stakeholders attribute legitimacy to organizations and organizations can directly influence such calculations and persuade key stakeholders through directly benefiting/involving their stakeholders. This legitimacy reflects "utility value of responsibility" [8]. Second, cognitive legitimacy concerns societal contexts that determine whether organizations' outputs, leader behaviors, and business practices are necessary or inevitable. This legitimacy works subconsciously and thereby it can be managed indirectly by organizations [34]. Third, moral legitimacy refers to normative evaluations and conscious moral judgments of the organization and its activities [35]. Moral legitimacy is "socially constructed by giving and considering reasons to justify certain actions, practices, or institutions" [8]. Explicit public discussion and vigorous participations by the firms are crucial for organizations to 
gain moral legitimacy [5]. According to Palazzo and Scherer [8], pragmatic and cognitive legitimacy are insufficient in global contexts (e.g., cognitive legitimacy assumes cultural homogeneity and density of shared norms, values, and beliefs) [5]. Thus, the two legitimacies need to be complemented by moral legitimacy [8].

\section{Why legitimacy of sharing economy has been challenged}

The legitimacy of sharing economy has been challenged due to concerns and issues of the sharing economy businesses' socially irresponsible practices. We comprehensively review concerns about sharing economy regarding regulatory/legal issues, tax/labor issues, consumer concerns, social inequality, politics and lobbying, economic/societal impact, and notion of sharing. We then further discuss how such issues impact pragmatic, cognitive, and moral legitimacy of sharing economy, followed by the discussions about how to manage challenged legitimacy (e.g., through more effective CSR communication).

\section{Regulatory and legal issues}

The growth of the sharing economy has attracted attention from governments, regulators, and industry incumbents. Government regulators recognize the benefits of the sharing economy, such as lower prices for consumers, flexible employment and extra income, better use of idle assets and new forms of business, better consumer experience, and the building of trust between consumers and businesses. However, they also recognize abundant problems, including income instability and fewer benefits than traditional jobs, lack of company oversight and untrained workers posing a danger to consumers, privacy dangers arising from collection of huge amounts of personal information, and a failure to get services to poorer consumers who lack smartphones or internet access [36]. Government efforts to integrate sharing economy businesses into existing regulatory frameworks could cause problems for Uber, Airbnb, and Lyft in regard to taxation, disability rules, worker classification, and consumer safety.

The issue arises that the regulations governing business practices, standards, and employee classification are outdated relics of the industrial era where the standards were meant to protect workers from factory exploitation [37]. Today, many workers work remotely as free agents and up to $90 \%$ of workers in the USA want more freedom in their choice of employment [37]. One estimate states that up to one third of American workers are in some way free agents (whether part-time or full-time, primary or secondary, etc.) [37]. Identifying how big this group is can be challenging as different definitions encompass full-time and part-time free agents, 1099 workers, freelancers, employers, etc. This diversity of types of free agents makes it cumbersome to draft new laws regulating businesses that employ free agents.

The three industry giants of sharing economy (i.e., Lyft, Uber, and Airbnb) employ half a million of the 2.7 million Americans in the sector [36]. But these companies, particularly Uber, identified their workers as independent contractors and tried to educate stakeholders on the benefits of the sharing economy until stakeholders realize the benefits themselves [38]. Both approaches worked when the players were small but are no longer feasible solutions. In response, California has now ruled that drivers are employees, not independent contractors. Further, Uber is now banned in the Hamptons 
area. Additionally, courts in many European countries have found that ride-sharing by non-professional drivers is illegal.

Regulators face the problem that data are necessary to make good policy decisions, but data about sharing economy are limited and hard to come by [36]. For instance, Airbnb refuses to release where its rental listings are located, thus limiting the power of local governments to regulate them [39]. The data that are available on the impact of the sharing economy on American workers and businesses has been compiled by special interest groups (often with questionable credibility), not unbiased government analysts [37]. There is no government-commissioned reporting on this sector to date.

Specific business practices of sharing economy also raise concerns about violations of anti-trust laws. One example is Uber's surge pricing, which Uber characterizes as an adaptive pricing model that is designed to equalize supply and demand through raising prices where there is high demand and few drivers [39]. Customers are notified when surge pricing is in effect. However, research shows that it is an artifice of Uber's active management, creating a "mirage of the marketplace," not actually connected to fluctuating supply and demand [39]. Uber's model raises concerns about violation of anti-trust laws because Uber drivers are independent contractors but agree on pricing; therefore, the pricing could be interpreted as collusion or price fixing [29]. Even further, some argue that these firms are attempting to create monopolies through such price fixing and cost advantages due to regulatory differences [40]. Uber faced a lawsuit in 2013 when New York taxi drivers filed for $\$ 100$ million in reimbursement damages for lost wages caused by Uber's cost advantages [41]. However, this lawsuit was thrown out by another judge recently because it was deemed "unfair." Despite its few encounters with litigation, Uber generally gets away with ignoring regulatory frameworks by accumulating vast sums of money for lawyers and lobbyists [41].

In the USA, there is no umbrella regulation affecting the sharing economy yet; rather, there is a patchwork of local ordinances and court rulings with disparate implications for each region [37]. Regulatory issues become worse in the context of global business. Other countries, such as China, are proactively establishing a national framework to make sharing economy a competitive business model. Such practices could endanger the success of US sharing economy players abroad [37].

For example, courts in many European countries have found that using non-professional drivers is illegal. South Korea banned the Uber app, hoping to encourage a locally produced competitor [38]. Uber is banned or heavily restricted in Belgium, France, Germany, Italy, and Spain due to taxi drivers petitioning the courts [29]. In California and Florida, courts have ruled that Uber must treat its drivers as employees and reimburse them for work costs and/or provide unemployment [29]. Uber drivers in the UK are petitioning for the same benefits. Airbnb has faced international challenges as well. The mayor of Paris set up a team of 20 agents to crack down on illegal room-sharing. This investigation led to 20 owners of 56 apartments incurring heavy fines for illegal room-sharing [38]. Catalonia in Spain is investigating how illegal room sharing affects tourism, pollution, and convenience stores [38]. In sum, regulatory and legal issues are growing across countries due to some malpractices of sharing economy businesses. Consequently, negative sentiments about sharing economy's legitimacy, particularly cognitive legitimacy, have increased. 


\section{Tax and labor issues}

Another major issue for sharing economy's legitimacy is driven by billions of dollars in missed tax revenue. The fees that sharing economy companies like Uber take are seldom taxed in the country where the transaction takes place, as the home offices are sheltered in tax haven countries such as Ireland. For instance, Uber processes transactions in the Netherlands and has its IP assigned to a tax haven in Bermuda, leaving less than $2 \%$ of its revenues taxable in the USA [42]. Airbnb collects up to $15 \%$ of the fee charged by room renters and then shelters it in Irish tax havens that allow it to operate on terms that are not available to its Hotelier competitors [42]. In Australia, Airbnb operates the Haines's Rental group, but the payments are automatically processed in Ireland. While Airbnb Ireland pays a small fee to its Australian subsidiary for in-country marketing (which is then taxed), the majority of money earned in Australia goes untaxed. At the very least, sharing economy players have alerted governments of the need to modernize taxation rules and combat companies shifting profits to tax havens.

An important labor issue is the classification of workers of sharing economy firms. Classifying these workers as contractors instead of employees brings up a myriad of issues: these workers have no minimum wage, have no ability to bargain, are unprotected by unemployment insurance, and receive no overtime pay. Unfortunately, labor concerns are prevalent among sharing economy companies that claim to liberate workers, particularly Uber. Because Uber calls its drivers independent contractors, Uber is not responsible for compensating them for insurance and benefits. Drivers receive no employer contribution for Medicare or Social Security, nor any unemployment insurance, and are responsible for their own expenses. Also, UberX, its cheapest service available to riders, has cut fares to $\$ 1.10$ per mile and $\$ .21 / \mathrm{min}$ under $11 \mathrm{mph}$ to compete with Lyft [43]. Uber also takes $20 \%$ of those earnings. However, an Uber driver's total costs (including insurance, gas, depreciation, and repairs) averages to $\$ .56$ per mile. This pricing barely leaves room for profit.

Additionally, multiple cases have been reported of violence against drivers, sometimes by passengers, and such injured workers are unprotected because of their employment status [29]. Uber states that it removes drivers with bad ratings, but there are reports that its executives remove drivers for personal and capricious reasons [39]. More savvy drivers have found that they do not make any money for short trips due to congestion and expenses and therefore avoid short trips. However, a low acceptance rate can cost them their job as Uber fires them if they go below a threshold [44]. Thus, drivers either lose money on a great number of rides or risk losing their extra source of income. Consequently, many drivers quit within a year. In sum, Uber's business model leaves drivers no recourse as it pits them against each other, discouraging collective action or forming a union for wage purposes. These same issues are also common in other countries.

\section{Consumer concerns}

Sharing economy was originally welcomed because of its convenient access and cheaper prices for services such as taxi rides, benefits which contributed to pragmatic legitimacy [5]. However, critics have challenged sharing economy services because of incidents that demonstrate the risks and lack of safeguards for customers [45]. For example, as a 
way to protect consumers, Uber provides users with an opportunity to rate drivers on its mobile app, but these ratings are the lightest form of consumer protection [46]. In 2017, a passenger who claimed that she was raped by an Uber driver in Kansas City filed a lawsuit against Uber, alleging that Uber ignored previous warnings that the driver did not fit with the company [47]. Similar rape incidents happened in India. In another case, an Uber driver was suspected of killing six people in Kalamazoo, Michigan, in 2016 [48]. In August 2017, a passenger in Florida was punched by his Uber driver during an argument about the fare and later died from the injuries. Sexual harassments by their drivers also led to two lawsuits in California and Kansas City [49]. According to one lawsuit,

Despite consistently marketing its driver background check process as "industry leading" and "more rigorous than what is required to become a taxi driver" - in reality Uber's application process is designed for speed, not safety [49].

For Airbnb, houses rented out by Airbnb do not have to meet any health or safety regulations. By comparison, hotels are held to stringent safety standards. Although safety of Airbnb rentals in the USA is less of a worry because of local ordinances (and structural and safety standards for condos and apartments), there is still worry for private residences and travel abroad. For instance, a Canadian woman who visited friends in Taiwan in 2013 stayed in an Airbnb rental which had a leaking water heater and lacked proper ventilation, leading to the woman's death from carbon monoxide poisoning [50]. In another incident, two people rented a house through Airbnb for Thanksgiving, but rope attached to a tree at the rental collapsed and fell on one person's skull, killing him. This accident could have been avoided at a $B \& B$ where a routine safety check, as required by law, could have revealed this danger. Juxtapose these stories with the fact that Uber and Airbnb tout their rating systems as a key benefit to consumers. But are they really? Furthermore, some critics are skeptical of Uber's rating algorithms and perceive Airbnb's rating system as intentionally misleading in order to misrepresent the level of quality [39].

\section{Social inequality}

Sharing economy has led to several issues about inequality as well. One issue is labor and capital and their relationship with income inequality. Those with capital (i.e., the relatively well-off) stand to gain a lot while those with only labor to sell/share stand to gain little [51]. Additionally, access to sharing economy can be limited, particularly for poorer people without smartphones, who thus lack access to cheaper services that the better-off can use [36].

Another issue is racial inequality in income earned through sharing economy. In the case of Airbnb, some research evidences that African Americans make 12\% less than non-African American hosts [52] because some renters with biased perceptions of African American hosts are apparently willing to pay a "premium" to stay in non-African Americans' houses. Another study found that a profile with an African American name was $16.6 \%$ less likely to be accepted by an Airbnb host than the same profile with a white name [53, 54]. Airbnb is being sued in a class action lawsuit for not doing enough about discrimination. 


\section{Politics and lobbying}

Airbnb and Uber appear to be heavily engaged in lobbying and PR. Legislators and regulators are having trouble deciding how to handle these new firms, and it seems Airbnb and Uber have more say in regulatory efforts than industry competitors do [39]. Difficulty in regulation is being exacerbated by a belief that such technology platforms are imminent/inevitable in a technology-driven future. Uber tried to quash New York mayor Bill De Blasio's effort to limit the number of cars on the road in 2015 [39]. In October 2015, Airbnb killed proposition F, an initiative to restrict short-term rentals, in San Francisco. It outspent its opponents by a ratio of 100:1 [39]. Additionally, both Uber and Airbnb are in no rush to go public for maximum flexibility; they provide no prospectus, they do not have an independent audit, and no one can see their accounts.

While Uber and Airbnb are becoming masters in leveraging big data analytics and convincing people that they know best how to improve efficiency and safety with this data [39], these firms control the narrative and only release figures that favorably portray them. Uber reported that its drivers could earn an average salary of $\$ 90 \mathrm{k} /$ year, but did not mention that this figure was based on the salaries of drivers in New York City, which has the highest wages of any city it operates in. Additionally, the fine print shows that this figure applies only to drivers driving over $40 \mathrm{~h}$ per week and does not include expenses (mileage, gas, repairs, insurance, etc.). Airbnb similarly released a press release claiming that "quantitative evidence shows hosts are good for NY." It reported that Airbnb supported 950 jobs in the outer boroughs and 82\% of its properties are outside of mid-Manhattan [39]. However, when the New York Attorney General's office examined the data, it was found that $97 \%$ of Uber's revenue came from just two of the five boroughs (Brooklyn and Manhattan) [39]. The claims are delivered in a confident tone with impressive figures but are misleading at best.

Airbnb has tempted academic researchers with access to its internal data. While it does not overtly commission researchers, the allure of exclusive access likely makes it difficult for researchers to maintain neutrality [39]. Once the researchers write their papers, Uber then uses those papers to refute claims by opponents. It "recruited" the former White House Economic Advisor Gene Sterling to write about its impact on housing prices and Princeton economist Alan Krueger to co-author a paper with Jonathan Hall, Uber's head of policy research, on driver income (the paper left out drivers' expenses, stating that the data was not available). Sometimes, Uber's reports are released in full but without the accompanying data, and other times, the reports are kept internal and only a press release is available [39]. Overall, the actions and reports of sharing economy giants do not exhibit transparency or considerations of their stakeholders. These actions lead to questions about these companies' level of responsibility and legitimacy.

\section{Economic and societal impact}

In many Western economies, big businesses and governments have not adequately invested in productivity, leading to low productivity and stagnating wages [42]. Sharing economy originated from economic recession but it currently operates on the periphery, not the center, of industry and disrupts traditional industries. It may 
increase competitions, but its introduction and disruption do not increase demand. Thus, some people argue that sharing economy creates little real economic impact-just a shift in who profits [3]. This argument and other evidence suggest that in the USA, workers are being pushed into this part of the economy because of stagnating wages and decreased standards of living. Further, these companies are trying to turn many other sectors in the economy into this form of "sharing," forcing incumbent players to compete on an unfair playing field regarding tax and regulatory requirements [42].

While sharing economy platforms make sense at the individual level, they create some macroeconomic concerns. For instance, these firms are changing communities. A report by Coldwell Banker Commercial told real estate investors around the USA that renting properties to Airbnb renters had a rate of return well over two times higher than renting to long-term renters, leading investors to prefer Airbnb renters and turning an already bad housing shortage into an ever more urgent crisis [44]. Airbnb is at the center of a set of cases against landlords in San Francisco where landlords have evicted their tenants in order to list their properties on Airbnb at elevated rates. Housing costs in San Francisco have been skyrocketing since the introduction of Airbnb, while Uber has added 10,000 more cars to London's already congested roads [40]. Amid worries about growing housing prices and a shortage of housing (only exacerbated by Airbnb's presence), Airbnb made a compromise with San Francisco lawmakers to cap the number of short-term rentals and have all their associates register with the city. However, only $20 \%$ of the 7000 associates did. Airbnb claims that it cannot be held responsible for illegal renting, citing the Communications Decency Act [55].

In the case of Canada, where the housing market has been on fire for about a decade, Airbnb is exacerbating the problem of housing shortages because many rental properties are being converted for Airbnb rentals leading to the eviction of hundreds of families. Investors do conversions of properties for Airbnb because of rising housing prices (and so want to cash in on huge capital gains). Airbnb encourages owners to rent their houses to short-stay visitors rather than long-term renters, causing rental prices to skyrocket and making it nearly impossible for renters to afford housing [41]. Hotels are also experiencing reduced demand, endangering profits. Airbnb causes problems for short-term renters as well. In Melbourne, Australia, short-term stayers are three times more likely to have complaints than long-term residents. Unfortunately, the remedies for complaints (at least in many Australian states) are more geared toward long-term residents. In other words, few city ordinances exist to deal with complaints from short-term stayers [46].

Critics also doubt whether ride-sharing platforms can create good jobs, especially in the case of Uber, which avoids regulation (sometimes even ignoring it) and shift risk onto the workers (all the while not providing any contractual obligations) [40]. Uber and Lyft drivers now outnumber taxi drivers in many major US cities. They are becoming a serious contributor to congestion [39]. Uber has been blamed for slowing traffic and increasing congestion in Manhattan, and meanwhile, taxi drivers earn less and Uber drivers are dismayed by their equally dismal net earnings [41, 46]. Additionally, public transit systems have been threatened by ride-sharing companies like Uber and Lyft poaching passengers [44]. Public transit systems require a precise equation that balances how to move people around the city. Ride-sharing services provide 
transportation to and from more remote places (where they incur a loss) by offsetting this cost with heavy use on busy areas (where they make their gains). However, these companies target the same segment of the population that public transit systems do. This passenger poaching makes it nearly impossible for public transit systems to be economically sustainable; potentially, the whole system could collapse, leading to disastrous reverberated effects. Additionally, less use of public transportation could negatively affect the environment as the benefits of shared transits (e.g., lower carbon emissions) are lost.

\section{Is sharing really sharing?}

Maybe one of the most important criticisms and the most challenging legitimacy issue is questions about its terminology: whether sharing economy is really sharing. Some argue that the sharing economy is less about sharing than selling because it is no different than traditional capitalism; it is only packaged with environmental, ethical, and moral claims [3]. Also, sharing economy allows customers to access unused assets at a price and make economic transactions for access with little personal interaction, so the phenomenon could be called access-based consumption rather than sharing [18, 25]. Others argue that sharing economy does nothing to change the traditional forms of ownership or move users into a more cooperative world. Instead, sharing economy commodifies and monetizes traditional forms of peer interaction and encourages a more individuated approach to the world.

For Airbnb, the initial idea of sharing extra bedrooms is good, but the idea has been converted to commercial businesses, particularly in big cities like New York and San Francisco. For instance, in New York City, many hosts control multiple listings and over 200 properties in some cases [44]. As mentioned earlier, the academic realm has no consensus on the definition of sharing economy, possibly because of differing interpretations of the act of sharing [10]. Many definitions of sharing economy do not fall into strict concepts of sharing. Some prior conceptualizations (e.g., Belk [20]) assume reciprocity and joint possessions, but these definitions do not truly reflect the practices of sharing economy services such as Airbnb [23]. Belk [20] distinguishes prototypical characteristics of sharing and commodity exchange. Later, Belk [16] identifies commercial car-sharing businesses such as Zipcar and for-profit home-sharing organizations like Airbnb as pseudo-sharing. According to Belk [16], such sharing is not prosocial sharing because "sharing includes voluntary lending, pooling and allocation of resources, and authorized use of public property (sharing), but not contractual renting, leasing, or unauthorized use of property by theft or trespass (pseudo-sharing)." Ozanne and Ballantine [56] argue that sharing behaviors reduce consumption of specific brands or product categories, and thus, they are an alternative to consumption: anti-consumption. Additionally, many of the initial startups that partook in sharing economy have quit operations or changed directions. Many of those who have stayed have ended the person-to-person narrative as a marketing technique and have begun to compete on price. Thus, the sharing economy has evolved to look less unique and revolutionary, a development which deepens the concerns about its legitimacy.

These comprehensive reviews of concerns about sharing economy are summarized in Table 1. 
Table 1 Summary of controversies and challenged legitimacy of sharing economy

\begin{tabular}{|c|c|}
\hline Controversy domains & Dark side of sharing economy and examples \\
\hline Regulatory and legal issues & $\begin{array}{l}\text { - Employee identification (e.g., Uber identifying their workers as independent } \\
\text { contractors } \\
\text { - Limited release of data for policy decisions (e.g., Airbnb refusing to release rental } \\
\text { listings) } \\
\text { - Possible violations of anti-trust laws (e.g., Uber's surge pricing model) }\end{array}$ \\
\hline Tax and labor issues & $\begin{array}{l}\text { - Missed tax revenues (e.g., Uber, Airbnb) } \\
\text { - Poor employee treatment and working environment (e.g., Uber's workers with } \\
\text { lack of protections and violence against drivers) }\end{array}$ \\
\hline Consumer concerns & $\begin{array}{l}\text { - Incidental situations with risks and lack of safeguards for customers (e.g., rape } \\
\text { and murder allegations, unmet health and safety regulations) }\end{array}$ \\
\hline Social inequality & $\begin{array}{l}\text { - Imbalanced distributions of gains across those with capital and without capital } \\
\text { - Racial inequality from discrimination }\end{array}$ \\
\hline Politics and lobbying & $\begin{array}{l}\text { - Lobbying and PR to legislators and regulators } \\
\text { - Allure of exclusive access to internal data offered to academic researchers }\end{array}$ \\
\hline $\begin{array}{l}\text { Economic and societal } \\
\text { impact }\end{array}$ & $\begin{array}{l}\text { - Increasing competitions rather than increasing demand } \\
\text { - Macroeconomic concerns (e.g., changing communities and worsening living } \\
\text { situations in concentrated service areas) } \\
\text { - Reduced use of public infrastructure that will adversely affect the benefit of } \\
\text { shared burden }\end{array}$ \\
\hline Is sharing really sharing? & $\begin{array}{l}\text { - Questions about sharing economy whether it is no different than traditional } \\
\text { capitalism in the end (e.g., commodifying and monetizing traditional forms of } \\
\text { peer interaction) }\end{array}$ \\
\hline
\end{tabular}

\section{CSR communications for legitimacy of sharing economy CSR communication}

As stated earlier, various issues with sharing economy have provoked serious concerns about its dark side. However, sharing economy businesses may be able to strengthen their legitimacy through CSR and CSR communication, which is closely related. A core assumption of all CSR-related terms (CSR, corporate citizenship, business ethics) is normative conformity with the social environment [57-60]. Prior CSR work indicates that firms that are perceived as socially responsible receive benefits such as consumers' positive attitudes toward the company/brands [61, 62]. CSR also contributes to firms' financial performance. Lins et al. [63], who utilize CSR as an indicator of social capital, confirm that firms with higher social capital (i.e., higher CSR) experienced stock returns 4-7\% points higher than did firms with lower social capital; higher CSR also led to other positive outcomes (e.g., higher profitability, growth, and sales per employee). In their investigation of 200 cross-industry suppliers-buyers' dyads, Homburg et al. [64] find that CSR practices enhance customer loyalty through trust and that philanthropic CSR increases customer loyalty through stronger customer-company identification. According to Cherney and Blair [65], perceived motives moderate the positive impact of CSR on consumers' perceptions of product performance (self-interest vs. benevolent). In contrast, some studies suggest that CSR may not always bring positive outcomes to organizations. Although consumers may form more positive (e.g., warmer, more compassionate) sentiments about firms with high CSR [66], they may perceive socially responsible firms' products/expertise as performing worse than those of companies without socially responsible actions $[67,68]$.

Effectively communicating CSR can benefit firms even in controversial industries. For instance, Du and Vieira [69] show that oil companies utilize a combination of 
CSR practices and communication (using factual arguments and two-sided messages) that often involves multi-media and social media platforms. They further suggest five communication tactics to boost and convey CSR credibility: (1) integrate CSR into corporate missions and values, (2) present factual arguments (e.g., state where money was donated, to whom it was donated, and the actual impact (whenever possible), (3) utilize two-sided persuasion (e.g., communicate both positive and negative information), (4) demonstrate the organization's leadership to industry-wide associations to address social concerns, and (5) showcase awards and certificates. In addition, using story-telling (i.e., creating affective stories about their CSR actions) can be more effective than argument-based advertising to enhance the impact of CSR communication.

From companies' perspective, using social media other than their websites can maximize their efforts to communicate CSR. In fact, many corporate websites are static and lack communication [70]. Considering that individuals' preferred methods of communication have shifted to social media channels such as YouTube and Facebook, where people show and share their lives and options, businesses could more effectively communicate CSR through social media. Other communication channels such as CSR blogs are valuable communication platforms for companies' CSR efforts, wherein organizations and highly engaged audiences can interact freely without any gate-keeping mechanism [70].

\section{CSR communication and legitimacy management}

Some researchers recognize that CSR debate is limited, particularly because research has been dominated by instrumental interpretations [8, 70, 71]. CSR discussions that primarily focus on pragmatic and cognitive conceptions of legitimacy reflect "theoretical narrowness, and missing rigor of the CSR debate, and lack of discourse on moral legitimacy" [8]. CSR and legitimacy can be more complicated and challenging for firms with global presence. Palazzo and Scherer [8] assert that current conceptualizations of CSR are built on the assumption that conformity with societal rules is the predictor of legitimacy, but the assumption does not work well in the global business context because there are no globally accepted legal or moral normative standards [72]. Along this line, Palazzo and Scherer [8] further state, "In the current transition from stable industrial society to a globalized postindustrial society, cognitive legitimacy is eroding (e.g., shareholder-value ideology, free and open market narratives, normative homogeneity) while pragmatic legitimacy (e.g., lobbyism, branding, strategic public relations) provokes growing resistance (e.g., anti-globalization movement, no logo movement). Therefore, moral legitimacy has become the core source of social acceptance."

In these aspects, legitimacy has emerged as one of the critical issues in companies that operate globally, and the importance of perceived moral legitimacy is growing [8]. How can companies manage legitimacy? Existing theories suggest two strategies: strategic approaches and institutional approaches. Strategic approaches assume that legitimacy serves as an operational resource [5] that business organizations can directly manage and influence [73]. Strategic approaches focus on pragmatic legitimacy and indicate the possibility that corporations can manipulate social contexts or the process of legitimacy ascriptions [8]. 
Institutional approaches treat legitimacy as the outcome of a business complying with normative values and societal beliefs, and this view of legitimacy reflects the embeddedness of organizational culture [34, 74]. Organizational legitimacy is also manifested through a continuous adaptation process of reacting and complying with external expectations for demonstrating organizations' worthiness and acceptability in a focal society [34]. In these aspects, institutional approaches are aligned with cognitive legitimacy, which assumes a national governance system and a homogeneous cultural background of shared norms, values, and beliefs [5]. CSR projects are ways to comply with external members' expectations [75] for achieving cognitive legitimacy. One important limitation of both strategic and institutional approaches, however, is that they show a lack of consideration of moral legitimacy [8].

Researchers such as Palazzo and Scherer [8] point out that current CSR communication has primarily focused on pragmatic and cognitive legitimacy. An increasing number of companies have communicated their CSR initiatives through various communication channels such as social reporting, websites, and advertising [70, 76]. CSR communication is crucial for companies to inform, educate, and more importantly, interact with stakeholders. In so doing, companies may directly influence pragmatic legitimacy and indirectly influence cognitive legitimacy of sharing economy. However, prior work has indicated that CSR communication may trigger corporate hypocrisy. According to Wagner et al. [77], who introduced the term "corporate hypocrisy," proactive CSR communication (vs. reactive CSR communication) develops a higher degree of hypocrisy, and consumers' firm beliefs and attitudes are negatively influenced where hypocrisy mediates the relationship.

\section{CSR communication for legitimacy of sharing economy}

For legitimacy of sharing economy, sharing economy businesses may need to harness CSR communication to enhance cognitive and moral legitimacy because of moral challenges of organizations such as Uber (e.g., the CEO's scandals involving sexual harassment in the workplace, etc.) $[5,75]$. Uber has striven to combat the negative reputation of its organizational culture, regulation issues, and other problems, which have lowered cognitive legitimacy [5]. Uber has recently committed $\$ 5$ million to prevent sexual assault and domestic violence through raising awareness and educating millions globally [78]. Also, Uber has launched significant charitable donations which it has communicated in social media such as Facebook with the hashtag \#GivingTuesday. In November 2017, it announced a partnership with Meals on Wheels America, a nationwide network of community-based organizations for seniors who needs support. Additionally, Uber announced in August 2017 that is working to close the gender gap in technology through a multiyear partnership with Girls Who Code, a national nonprofit organization. As part of the partnership, Uber will give \$1.2 million to Girls Who Code over the next 3 years to help grow hundreds of after-school and immersion programs and allow an additional 60,000 girls across the USA to be exposed to technical skills [4]. This donation is part of a $\$ 3$ million diversity fund to be spent in the coming years. In October 2017, Uber launched 8-80 Coding, a new initiative for technology education for people of all ages in Philadelphia. This initiative includes three programs: (1) support for students to be certified as AWS Solutions Architect Associates, (2) free 
tech education for children ages 5-18, and (3) a program working to close the gender gap in technology by helping middle school girls get coding education [79]. Additionally, Uber claims that it shows how technology can serve ethical roles in society. Essentially, with feedback from law enforcement, Uber is trying to modify its processes and policy for public and private safety [80].

Uber's Facebook fan page seems to show high interactions between the firm and customers, but many comments are negative. Customers mostly report negative experiences, complaints, and anger, but Uber has indeed responded quickly and proactively to comments. The company apologizes, say it takes such issues seriously, asks people to send private messages, and then responds again, even several times to the same person. These efforts indicate that the company at least cares about its focal social media platform. Its website, however, lacks prompt CSR communication, as does its Facebook fan page. Its stories, partnerships, and promotions are mostly about golf, holidays, free rides, and UberEATS. Only late in 2017 did Uber begin taking more active positions and communicating its ethical roles in the community and society. Its response to negative incidents is reactive CSR communication. For instance, Dara Khosrowshahi, CEO, posted on November 21, 2017, about a data security incident in 2016 [81]. In other words, the timing of these responses needs to be improved. Overall, active involvement and vigorous participation in explicit public discussion can help sharing economy businesses improve moral legitimacy, which has become more crucial for global organizations $[5,8]$.

\section{Discussion and theoretical implications}

Sharing economy has taken over a substantial proportion of consumers' lives, rapidly and widely. The global success stories of sharing economy firms such as Uber and Airbnb have demonstrated the positive side of sharing economy. But various issues with the concept of sharing economy and businesses' practices have led critics to challenge the legitimacy of sharing economy. Building upon legitimacy theory [5], this paper comprehensively reviews sharing economy, including its positive and negative aspects and controversies and concerns about its legitimacy. We further synthesize CSR and CSR communication literature and link CSR and CSR communication to improved legitimacy. Using a theoretical lens, this paper addresses some important questions: where sharing economy stands now in terms of three types of legitimacy and how sharing economy companies may need to manage legitimacy to justify their existence and build long-term success.

Specifically, sharing economy has maintained pragmatic legitimacy in that the benefits are overall clearly recognized by self-interested stakeholders [5]. Also, the growth and the profit of sharing economy firms aligns with early theories of profit such as Levitt's, who hold that making a profit is the social responsibility of for-profit organizations [8]. But concerns about consumer safety and unstable employment issues have lowered pragmatic legitimacy because the benefits from sharing economy-for either consumers or workers-are offset by such security issues.

More importantly, critics have also challenged the cognitive and moral legitimacy of sharing economy businesses and responding to these challenges may be more important for these companies to justify their presence and build long-term success [8]. Responding to challenges to cognitive and moral legitimacy may be more difficult than 
responding to challenges to pragmatic legitimacy because cognitive and moral legitimacies work at a subconscious level, so organizations are only able to indirectly influence customers' perceptions [5, 34]. Up to now, sharing economy businesses, especially the major players Uber and Airbnb, have faced negative perceptions about their value and social impact. These conflicts have resulted from their malpractices and incidents involving regulations; legal, tax, and labor issues; politics; and lobbying behaviors. Also, the issues of social inequality and societal and economy impact, along with doubts about its core concept of sharing, are also weakening its legitimacy. These negative perceptions highlight the dark side of sharing economy [14], a topic which is neglected in the literature. As one of the first attempts to explore the negative side of sharing economy, the current research brings attention to how and why the cognitive and moral legitimacy of sharing economy has been challenged.

We also link the legitimacy of sharing economy to CSR of sharing economy. Legitimacy is a yardstick in CSR debate [7]. Within the global environment where cognitive legitimacy is eroding and pragmatic legitimacy is provoking resistance [8], sharing economy has more challenges of its legitimacy. Sharing economy firms have realized the value of CSR and embarked upon several CSR initiatives that can contribute to cognitive legitimacy [75]; however, these initiatives have not been well communicated. We argue that effective CSR communications as well as practicing CSR are crucial to combat the rising negative sentiments about legitimacy. Particularly, engaging key stakeholders (e.g., local communities) in decision and communication processes contributes to legitimacy $[8,35]$. CSR can be used as a strategic means to achieve legitimacy and combat negative sentiments [82], even in controversial industries like the oil industry [69]. Thus, harnessing CSR and CSR communication can be viable and valuable for sharing economy businesses to legitimize their activities [83, 84]. In other words, innovative services like sharing economy interrupt traditional business and may get challenged for its legitimacy; thus, incorporating doing good for the society for smart future and for the environmental sustainability can help sharing economy to restore its legitimacy in the current time $[85,86]$. Also, In sum, as one of the first studies of the dark side and challenged legitimacy of sharing economy, the current paper makes theoretical contributions from comprehensive theory-based reviews of why and how the legitimacy of sharing economy has been challenged, despite very positive (initial) reactions to sharing economy. It also offers insights into better approaches to resolve the challenged legitimacy of sharing economy through CSR communication. The discussion of how CSR contributes to the legitimacy of sharing economy is a valuable expansion of CSR discourse.

\section{Practical implications}

One of the biggest issues for sharing economy businesses is how to improve challenged legitimacy. First, we suggest that businesses can enhance legitimacy and combat negative sentiments with CSR communication via multi-media platforms and social media platforms. Particularly, businesses must be more proactive in engaging key stakeholders (e.g., local communities) in the communication process. Also, Du and Vieira's [69] five tactics to boost CSR credibility can help sharing economy businesses increase legitimacy through effective CSR communication. Importantly, Du and Vieira argue that the impact of those tactics may depend on the firm size: the larger the company, the more 
effective the tactics (because of larger businesses' resources, motives, and possibility of better design). Sharing economy firms are growing exponentially not only in firm value but also in firm size. These sharing economy firms should then harness their firm size to boost their legitimacy (strategic, cognitive, and more importantly, moral) through more proactive CSR engagement and communication.

Next, given concerns about consumer safety and labor issues, sharing economy businesses must devise more sophisticated measures to protect privacy and security. Rather than relying on mere claims (e.g., Uber's "we conduct rigorous background check for our drivers") or simple rating systems, businesses need some type of real guarantees and more sophisticated, specific measurement systems to enhance trust [87], all of which can contribute to pragmatic legitimacy. This matter can be easier to manage with more sophisticated measurement tools, as pragmatic legitimacy can be directly influenced by firms [5].

Additionally, resolving labor and work environment issues is essential for enhanced legitimacy, particularly cognitive legitimacy. Although the concerns addressed above are legitimate, issues about work environments apply not only to sharing economy. As shown by Uber's case, companies which neglect fair work environments and fail to avoid scandal face serious backlash.

\section{Limitation and future research}

The current study has several limitations, which can be venue for future research. For instance, given the significant role of trust in sharing economy suggested by some researchers [23], future research can integrate the role of trust in the legitimacy framework. For instance, a valuable extension would be to explore how lowered legitimacy of sharing economy due to several issues may interplay with the societal and consumers' trust and how their CSR communication play a role in managing challenged legitimacy of sharing economy. According to Huurne et al.'s [23] comprehensive, systemic review of the role of trust in general consumer-to-consumer e-commerce and sharing economy, people's trust in sharing economy is driven by various factors such as reputation, interactive experiences, and trust in the platform, and trust involves multiple entities (i.e. seller, buyer, platform, interpersonal, and transaction). To date, as trust in the sharing economy has received very limited attention [23], the integrative discussion of legitimacy and trust can provide a more comprehensive picture.

The current research provides valuable discussions of the challenged legitimacy of sharing economy. Yet, we did not take an empirical approach. Future research should empirically quantify the impact of various issues on the perceived legitimacy of sharing economy. In so doing, more interdisciplinary approaches to studies of organizations and more attention to moral legitimacy would offer valuable insights [8].

Acknowledgements

Not applicable

Funding

Not applicable 


\section{Author's contributions}

$\mathrm{JH}$ has solely initiated this particular study and developed the manuscript. The author read and approved the final manuscript.

\section{Author's information}

Assistant Professor of Marketing and Margaret Van Hoy Hill Dean's Notable Scholar at Bryan School of Business \& Economics, University of North Carolina at Greensboro, USA. She holds her Ph.D. in retailing and consumer studies from Ohio State University and M.S. in international retailing from Michigan State University. Her past and current industry experience includes positions as a marketer, business consultant, columnist, and market analyst for various global companies. Her research interests include the impact of conscious capitalism on traditional business and consumers, sharing economy, and social innovation. She has published articles in Journal of Business Research, European Journal of Marketing, Journal of Small Business Management and Journal of Services Marketing, among others. She can be contacted at j_hwang3@uncg.edu.

\section{Competing interests}

The author declares that she has no competing interests.

\section{Publisher's Note}

Springer Nature remains neutral with regard to jurisdictional claims in published maps and institutional affiliations.

\section{Received: 19 October 2018 Accepted: 10 December 2018}

Published online: 11 January 2019

\section{References}

1. Airbnb (2017) About us. https://www.airbnb.com/about/about-us. Accessed 28 Nov 2017.

2. Uber (2017a) 5 billion trips. https://www.uber.com/newsroom/5billion-2/. Accessed 1 Dec 2017.

3. Killick R (2015) 'Sharing economy' companies like Uber and Airbnb aren't really 'sharing' anything. http://www. businessinsider.com/sharing-economy-companies-like-uber-and-airbnb-arent-really-sharing-anything-2015-10. Accessed 27 Oct 2017.

4. Dickey MR (2017) Uber gives $\$ 1.2$ million to girls who code. https://techcrunch.com/2017/08/24/uber-gives-1-2-millionto-girls-who-code/. Accessed 28 Nov 2017.

5. Suchman MC (1995) Managing legitimacy: strategic and institutional approaches. Acad Manag Rev 20(3):571-610.

6. Weber M (1978) Economy and Society: An Outline of Interpretive Sociology. Berkeley, CA: University of California Press

7. Sethi SP (1975) Dimensions of corporate social performance: an analytical framework. Calif Manag Rev 17(3):58-64.

8. Palazzo G, Scherer AG (2006) Corporate legitimacy as deliberation: a communicative framework. J Bus Ethics 66(1):71-88.

9. Botsman R, Rogers R (2010) What's mine is yours: the rise of collaborative consumption. Harper Business, New York.

10. Bucher E, Fieseler C, Lutz C (2016) What's mine is yours (for a nominal fee)-exploring the spectrum of utilitarian to altruistic motives for internet-mediated sharing. Comput Hum Behav 62:316-326.

11. Hwang J, Griffiths M (2017) Share more, drive less: Millennials value perception and behavioral intent in using collaborative consumption services. J Consum Mark 34(2):132-146.

12. Lawson SJ, Gleim MR, Perren R, Hwang J (2016) Freedom from ownership: an exploration of access-based consumption. J Bus Res 69(8):2615-2623.

13. Martin CJ, Upham P, Budd L (2015) Commercial orientation in grassroots social innovation: insights from the sharing economy. Ecol Econ 118:240-251.

14. Malhotra A, Van Alstyne M (2014) The dark side of the sharing economy... and how to lighten it. Commun ACM 57(11): 24-27.

15. Benkler $Y$ (2004) Sharing nicely: on shareable goods and the emergence of sharing as a modality of economic production. Yale Law J 114(2):273-358.

16. Belk R (2014) You are what you can access: sharing and collaborative consumption online. J Bus Res 67(8):1595-1600.

17. Martin CJ (2016) The sharing economy: a pathway to sustainability or a nightmarish form of neoliberal capitalism? Ecol Econ 121:149-159.

18. Bardhi F, Eckhardt GM (2012) Access-based consumption: the case of car sharing. J Cons Res 39(4):881-898

19. Gasnky L (2010) The mesh: why the future of business is sharing. Penguin, New York.

20. Belk R (2010) Sharing. J Cons Res 36(5):715-734.

21. Botsman R (2015) Thinking. http://rachelbotsman.com/thinking/. Accessed 28 Oct 2017.

22. Owyang J (2015) The new rules of the collaborative economy, 2015 data on the rise of sharing. http://www.webstrategist.com/blog/2015/10/05/report-the-new-rules-of-the-collaborative-economy-2015-data-on-the-rise-of-sharing/. Accessed 15 Oct 152017

23. Huurne M, Ronteltap A, Corten R, Buskens V (2017) Antecedents of trust in the sharing economy: a systematic review. J Consum Behav 16(6):485-498.

24. Habibi MRM, Kim A, Laroche M (2016) From sharing to exchange: an extended framework of dual modes of collaborative nonownership consumption. J Assoc Consum Res 1(2):277-294.

25. Kessler S (2015) The sharing economy is dead and we killed it. https://www.fastcompany.com/3050775/the-sharingeconomy-is-dead-and-we-killed-it. Accessed 1 Oct 2017.

26. Belk R (2013) Extended self in a digital world. J Consum Res 40(3):477-500.

27. Scholz, T. (2014). Platform cooperativism vs. the sharing economy. https://medium.com/@trebors/platformcooperativism-vs-thesharing-economy-2ea737f1b5ad. Accessed 25 Sept 2017.

28. Lamberton CP, Rose RL (2012) When is ours better than mine? A framework for understanding and altering participation in commercial sharing systems. J Mark 76(4):109-125. 
29. Petropaulous G (2016) Uber and the economic impact of sharing economy platforms. http://bruegel.org/2016/02/uberand-the-economic-impact-of-sharing-economy-platforms/. Accessed 20 Oct 2017.

30. Hong J (2017) How China's ride-hailing king DiDi is taking over the world before Uber can. http://www.forbes.com/ sites/jinshanhong/2017/08/03/how-chinas-ride-hailing-king-didi-is-taking-over-the-world-before-uber-can/\#56abf8503fd8. Accessed 22 Sept 2017

31. Schmidt GM, Druehl CT (2008) When is a disruptive innovation disruptive? J Prod Innov Manag 25(4):47-369.

32. Sacks D (2011) The sharing economy. https://www.fastcompany.com/1747551/sharing-economy. Accessed 23 Aug 2017.

33. Oliver C (1996) The institutional embeddedness of economic activity. In: Baum J, Dutton J (eds) Advances in strategic management, vol 13. JAl Press, Greenwich, pp 163-189.

34. Oliver C (1991) Strategic responses to institutional processes. Acad Manag Rev 16(1):145-179.

35. Aldrich HE, Fiol CM (1994) Fools rush in? The institutional context of industry creation. Acad Manag Rev 19(4):645-670.

36. Roberts J (2016) 5 things to know about how the feds see the 'sharing' economy. http://fortune.com/2016/06/03/ commerce-sharing-economy/. Accessed 2 Aug 2017.

37. Morgan J, Severson E (2015) Are Uber, Airbnb and other sharing economy businesses good for America? http://www. forbes.com/sites/jacobmorgan/2015/12/17/are-uber-airbnb-and-other-sharing-economy-businesses-good-for-america/ \#c2c06ef6964d. Accessed 9 Sept 2017.

38. Marchi A, Parekh EJ (2015) How the sharing economy can make its case. http://www.mckinsey.com/business-functions/ strategy-and-corporate-finance/our-insights/how-the-sharing-economy-can-make-its-case. Accessed 23 Sept 2017.

39. Slee T (2016) The sharing economy's dirty laundry. https://www.jacobinmag.com/2016/03/uber-airbnb-sharingeconomy-housing-tech/. Accessed 12 Oct 2017.

40. McCann D (2015) The sharing economy: The good, the bad and the real. https://neweconomics.org/2015/12/thesharing-economy-the-good-the-bad-and-the-real. Accessed 2 Oct 2017.

41. West J (2016) Ownside of Uber, Airbnb is disrupted Canadian economy. http://campfire-capital.com/retail-innovation/ logistics-and-delivery-innovation/downside-to-uber-airbnb/. Accessed 27 Sept 2017.

42. Kocieniewski D (2016) The sharing economy doesn't share the wealth. http://www.bloomberg.com/news/articles/201604-06/the-sharing-economy-doesn-t-share-the-wealth. Accessed 15 Sept 2017.

43. Asher-Schapiro A (2014) Is Uber's business model screwing its workers?. http://inthesetimes.com/working/entry/17201/ uber_s_business_model_screwing_its_workers. Accessed 16 Aug 2017.

44. Hill S (2016) How the sharing economy screws American workers. http://www.huffingtonpost.com/steven-hil//sharingeconomy-american-workers_b_9018724.html. Accessed 28 Aug 2017.

45. Rauch DE, Schleicher D (2015) Like Uber, but for local government law: the future of local regulation of the sharing economy. Ohio St LJ 76:901.

46. Jericho G (2016) The dark side of Uber: why the sharing economy needs tougher rules. https:/www.theguardian.com/ business/grogonomics/2016/apr/18/uber-airbnb-sharing-economy-tougher-rules-australia. Accessed 15 Oct 2017.

47. Dickey MR (2017) Lawsuit claims Uber ignored attempted murder conviction of driver who later raped passenger. https:/techcrunch.com/2017/06/28/lawsuit-claims-uber-ignored-attempted-murder-conviction-of-driver-who-later-rapedpassenger/. Accessed 25 Sept 2017.

48. Chen K (2016) Uber driver suspected of killing 6 reportedly picked up passengers before and after shootings. https:/www. huffingtonpost.com/entry/kalamazoo-shooter-uber-passengers_us_56ca6f97e4b0928f5a6c5612. Accessed 25 Aug 2017.

49. Bhuiyan J (2017) Uber is being sued by two separate women claiming sexual assault by its drivers. https://www.recode. net/2017/6/30/15904770/uber-lawsuit-sexual-assault-negligence-background-checks. Accessed 22 Sept 2017.

50. Bonnington C (2015) The tragic Airbnb problem you've probably never thought about. http://www.refinery29.com/ 2015/11/97263/airbnb-safety-regulation-controversy. Accessed 28 Aug 2017.

51. Griswold A (2016) Airbnb and Uber are the next frontier in the struggle between capital and labor. http://qz.com/ 625360/what-uber-and-airbnb-might-mean-for-income-inequality-in-the-us/. Accessed 27 Sept 2017.

52. Zaffar $E$ (2015) The sharing economy is causing inequality, social harm.

53. http://www.huffingtonpost.com/ehsan-zaffar/the-sharing-economy-is-ca_b_8765450.html. Accessed 29 Sept 2017.

54. Edevane G (2016) Airbnb slapped with suit for alleged discrimination against black guests. http://mashable.com/2016/05/19/ airbnb-lawsuit-racism-discrimination/?utm_cid=mash-com-social-huffpo-partner\#n8ZAhWkWgkgK. Accessed 27 Sept 2017.

55. Benner K (2016) Airbnb in disputes with New York and San Francisco. https://www.nytimes.com/2016/06/29/ technology/airbnb-sues-san-francisco-over-a-law-it-had-helped-pass.html. Accessed 25 Oct 2017.

56. Ozanne LK, Ballantine PW (2010) Sharing as a form of anti-consumption? An examination of toy library users. J Consum Behav 9(6):485-498.

57. Carroll AB (1979) A three-dimensional conceptual model of corporate performance. Acad Manag Rev 4(4):497-505.

58. Carroll AB (1998) The four faces of corporate citizenship. Bus Soc Rev 100(1):1-7.

59. Maignan I, Ferrell OC (2000) Measuring corporate citizenship in two countries: the case of the United States and France. J Bus Ethics 23(3):283-297.

60. Wood DJ (1991) Corporate social performance revisited. Acad Manag Rev 16(4):691-718.

61. Sen S, Bhattacharya CB (2001) Does doing good always lead to doing better? Consumer reactions to corporate social responsibility. J Mark Res 38(2):225-243.

62. Wigley S (2008) Gauging consumers' responses to CSR activities: does increased awareness make cents? Public Relat Rev 34(3):306-308.

63. Lins KV, Servaes H, Tamayo A (2017) Social capital, trust, and firm performance: the value of corporate social responsibility during the financial crisis. J Financ 72(4):1785-1824.

64. Homburg C, Stierl M, Bornemann T (2013) Corporate social responsibility in business-to-business markets: how organizational customers account for supplier corporate social responsibility engagement. J Mark 77(6) 54-72.

65. Chernev A, Blair S (2015) Doing well by doing good: the benevolent halo of corporate social responsibility. J Consum Res 41(6):1412-1425.

66. Aaker J, Vohs KD, Mogilner C (2010) Nonprofits are seen as warm and for-profits as competent: firm stereotypes matter. J Consum Res 37(2):224-237. 
67. Luchs MG, Naylor RW, Irwin JR, Raghunathan R (2010) The sustainability liability: potential negative effects of ethicality on product preference. J Mark 74(5):18-31.

68. Newman GE, Gorlin M, Dhar R (2014) When going green backfires: how firm intentions shape the evaluation of socially beneficial product enhancements. J Consum Res 41(3):823-839.

69. Du S, Vieira ET (2012) Striving for legitimacy through corporate social responsibility: insights from oil companies. J Bus Ethics 110(4):413-427.

70. Matten D, Crane A (2005) Corporate citizenship: toward an extended theoretical conceptualization. Acad Manag Rev 30(1):166-179.

71. Jones TM (1995) Instrumental stakeholder theory: a synthesis of ethics and economics. Acad Manag Rev 20(2):404-437.

72. Habermas J (2001) The postnational constellation: political essays. MIT Press, Cambridge.

73. Ashforth BE, Gibbs BW (1990) The double-edge of organizational legitimation. Organ Sci 1(2):177-194

74. DiMaggio P, Powell W (1983) The iron cage revisited: institutional isomorphism and collective rationality in organizational fields. Am Sociol Rev 48(2):147-160.

75. Waddock S (2004) Creating corporate accountability: fundamental principles to make corporate citizenship real. J Bus Ethics 50(4):313-327.

76. Birth G, Illia L, Lurati F, Zamparini A (2008) Communicating CSR: practices among Switzerland's top 300 companies. Corp Commun An Int J 13(2):182-196.

77. Wagner T, Lutz RJ, Weitz BA (2009) Corporate hypocrisy: overcoming the threat of inconsistent corporate social responsibility perceptions. J Mark 73(6):77-91.

78. Uber (2017) Driving change - Uber's $\$ 5$ million commitment to prevent sexual assault and domestic violence. https:// www.uber.com/newsroom/driving-change-together/. Accessed 28 Nov 2017.

79. Uber (2017) 8-80 coding: Supporting tech for all ages in Philadelphia. https://www.uber.com/newsroom/8-80-coding/ Accessed 28 Nov 2017.

80. Uber (2017) Uber shows how tech can play an ethical role in both privacy and public safety. https:/www.uber.com/ newsroom/safety-and-security/. Accessed 28 Nov 2017.

81. Uber (2017) 2016 data security incident. https://www.uber.com/newsroom/2016-data-incident/. Accessed 1 Dec 2017.

82. Bhattacharya CB, Sen S (2004) Doing better at doing good: when, why, and how consumers respond to corporate social initiatives. Calif Manag Rev 47(1):9-24.

83. Du S, Bhattacharya CB, Sen S (2007) Reaping relational rewards from corporate social responsibility: the role of competitive positioning. Int J Res Mark 24(3):224-241

84. Perks KJ, Farache F, Shukla P, Berry A (2013) Communicating responsibility-practicing irresponsibility in CSR advertisements. J Bus Res 66(10):1881-1888.

85. Lee S (2018) Innovation: from small "I" to large "I". Int J Qual Innov 4(2). https://doi.org/10.1186/s40887-018-0022-4.

86. Lee S (2015) The age of quality innovation. Int J Qual Innov 1(1). https://doi.org/10.1186/s40887-015-0002-x.

87. Möhlmann M (2016) Digital trust and peer-to-peer collaborative consumption platforms: a mediation analysis. https:// papers.ssrn.com/sol3/papers.cfm?abstract_id=2813367. Accessed 11 Nov 2017.

\section{Submit your manuscript to a SpringerOpen ${ }^{\circ}$ journal and benefit from:}

- Convenient online submission

Rigorous peer review

- Open access: articles freely available online

High visibility within the field

- Retaining the copyright to your article

Submit your next manuscript at $\boldsymbol{\nabla}$ springeropen.com 